\title{
Chemical and electrocatalytic ammonia oxidation by ferrocene
}

\author{
Mahdi Raghibi Borougeni, Christine Greene, Jeffery A. Bertke, and Timothy H. Warren* \\ Department of Chemistry, Georgetown University, Box 571227, Washington, DC 20057, USA. \\ *email: thw@georgetown.edu
}

\begin{abstract}
Recognizing the potential of ammonia to serve as a carbon-free fuel, we describe an electrocatalytic system for the oxidation of ammonia based on ferrocene $\left(\mathrm{Cp}_{2} \mathrm{Fe}\right)$, an inexpensive, robust catalyst utilizing Earth-abundant iron. Ferrocenium $\left(\mathrm{Cp}_{2} \mathrm{Fe}^{+}\right)$, the 1-electron oxidized form of ferrocene, cleanly oxidizes ammonia to generate nitrogen gas $\left(\mathrm{N}_{2}\right)$ and protons captured by excess ammonia as $\mathrm{NH}_{4}{ }^{+}$with electrons reducing ferrocenium to ferrocene. This process occurs under electrocatalytic conditions to generate $\mathrm{N}_{2}$ with sustained current. Simple modification of ferrocene through sulfonation allows for solubility in liquid ammonia to enable electrocatalysis in highly concentrated, energy dense solutions of ammonia. Kinetic and computational analysis provides mechanistic insight into the oxidation of ammonia by ferrocenium.
\end{abstract}


Ammonia $\left(\mathrm{NH}_{3}\right)$ represents a promising carbon-free fuel. ${ }^{1-3}$ Produced on a scale of over $175 \mathrm{M}$ tons / y primarily for fertilizer applications, ${ }^{4}$ liquified ammonia $\left(25{ }^{\circ} \mathrm{C}, 10 \mathrm{bar}\right)$ is energy-dense at $13.5 \mathrm{GJ} / \mathrm{m}^{3}$ compared to high pressure hydrogen (700 bar) that only has a density of $5.3 \mathrm{GJ} / \mathrm{m}^{3}{ }^{5}$. Due to its extensive use in agriculture, a global transportation network exists for ammonia delivery that includes sea shipping routes and terrestrial pipelines. Coupled with electrochemical ammonia production from renewable resources, ${ }^{6,7}$ efficient extraction of energy from ammonia enables a carbon-free fuel cycle. ${ }^{8}$

While ammonia possesses essentially the same fuel value on a hydrogen atom basis as hydrogen gas, strong $\mathrm{N}-\mathrm{H}$ bonds $(\mathrm{BDE}=108.2 \mathrm{kcal} / \mathrm{mol})$ must be broken en route to the robust triple bond of $\mathrm{N}_{2}(226$ $\mathrm{kcal} / \mathrm{mol}){ }^{9}$ Thus, catalysts are required to efficiently employ ammonia in fuel applications. Conversion of ammonia to its constituent elements highlights ammonia as a hydrogen storage vector (Fig. 1A). ${ }^{5}$ Transition metals as well as alkali metals promote ammonia decomposition at $400-600{ }^{\circ} \mathrm{C}^{10}$ while catalyzed electrolysis occurs at lower temperatures but with high overpotentials, ${ }^{11-13}$ each approach generating hydrogen for potential use in a fuel cell. On the other hand, conversion of ammonia to nitrogen gas, protons, and electrons (Fig. 1A) enables the direct use of ammonia in a fuel cell. While a number of heterogeneous anodes have been developed for ammonia oxidation at high temperatures, advances are still required to increase the rate and lower the overpotential. $8,10,14,15$

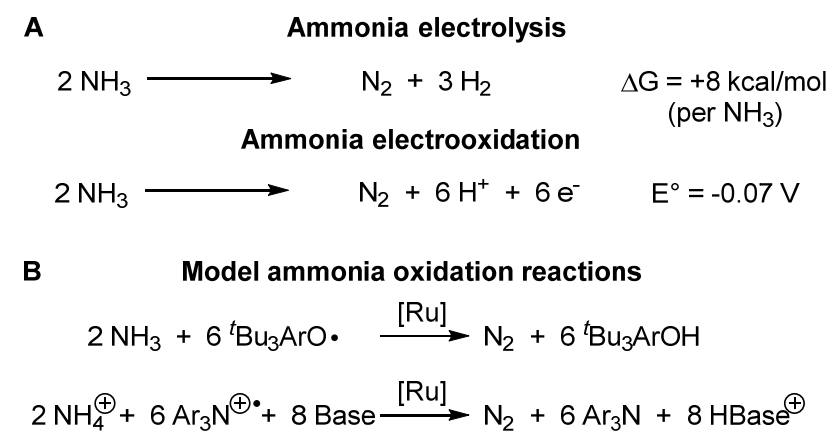

Figure 1 Ammonia oxidation reactions. (A) Thermodynamics of ammonia an energy carrier. (B) Model ammonia oxidation reactions explored with precious metal molecular catalysts based on $\mathrm{Ru} .^{16,17}$

Coordination complexes enable opportunities to outline mechanistic pathways that can lead to innovations in electrocatalyst design. ${ }^{18,19}$ Transition metal complexes stoichiometrically convert ammonia to nitrogen in the presence of appropriate oxidants ${ }^{20,21}$ or under electrochemical forcing, ${ }^{22}$ while a molybdenum complex releases hydrogen from bound ammonia under mild conditions. ${ }^{23}$ Coupling these steps, a molecular complex based on the precious metal ruthenium catalyzes the electrolysis of $\mathrm{NH}_{3}$ to $\mathrm{N}_{2}$ and $\mathrm{H}_{2}$ (Fig. 1A). ${ }^{24}$ Other model reactions catalyzed by molecular ruthenium complexes include the $\mathrm{H}$-atom abstraction of ammonia by the 2,4,6-tri-t-butylphenoxyl radical ${ }^{t} \mathrm{Bu}_{3} \mathrm{ArO}{ }^{16}$ as well as oxidation of ammonium $\left(\mathrm{NH}_{4}{ }^{+}\right)$in the presence of a specialized base or under electrochemical cycling (Fig. 1B). ${ }^{17}$ 
Sustainability concerns strongly motivate the development of inexpensive catalysts based on Earth-abundant metals, especially ones that can function in energy-dense liquid ammonia. In this light, we considered the ferrocenium / ferrocene $\left(\mathrm{Fc}^{+} / \mathrm{Fc}\right)$ redox couple for the catalytic oxidation of ammonia (Fig. 2A). This simple organometallic system serves as an electrocatalyst for the oxidation of $1^{\circ}, 2^{\circ}$, and $3^{\circ}$ amines such as propylamine, diethylamine, and trimethylamine. ${ }^{25}$ Ferrocene is exceptionally thermally and electrochemically stable, ${ }^{26}$ recommended by IUPAC as a reference for non-aqueous solvents. ${ }^{27,28}$ Moreover, ferrocene is a commodity chemical available at a cost of dollars / $\mathrm{kg}$ whose derivatives are ubiquitous across varied fields of chemistry. ${ }^{26}$

\section{Results}

Chemical Ammonia Oxidation by Ferrocenium. Ferrocenium $\left(\mathrm{Fc}^{+}\right)$, the one electron oxidized form of ferrocene, cleanly converts ammonia $\left(\mathrm{NH}_{3}\right)$ to dinitrogen $\left(\mathrm{N}_{2}\right)$ (Figure $\left.2 \mathrm{~A}\right)$. Addition of excess ammonia gas to a solution of ferrocenium hexafluorophosphate $\left(\mathrm{FcPF}_{6}\right)$ in acetonitrile $(\mathrm{MeCN})$ at room temperature results in rapid conversion of $\mathrm{Fc}^{+}$to $\mathrm{Fc}$ with concomitant formation of $\mathrm{N}_{2}$ and $\mathrm{NH}_{4}{ }^{+}$. Recognizing that the oxidation of $\mathrm{NH}_{3}$ to $\mathrm{N}_{2}$ is an overall $6 \mathrm{e}^{-}$reaction that consumes 6 equiv. $\mathrm{Fc}^{+}$, analysis of the headspace by GC-TCD reveals $95 \%$ yield of $\mathrm{N}_{2}$ whereas ${ }^{1} \mathrm{H}$ NMR analysis indicates the formation of $\mathrm{Fc}$ in $90-100 \%$ yield. Protons derived from the oxidation of ammonia are captured by excess ammonia and appear in quantitative yield as $\mathrm{NH}_{4}{ }^{+}$, isolated as $\left[\mathrm{NH}_{4}\right] \mathrm{PF}_{6} \bullet{ }^{1} / 3 \mathrm{NH}_{3}$ under our workup conditions.

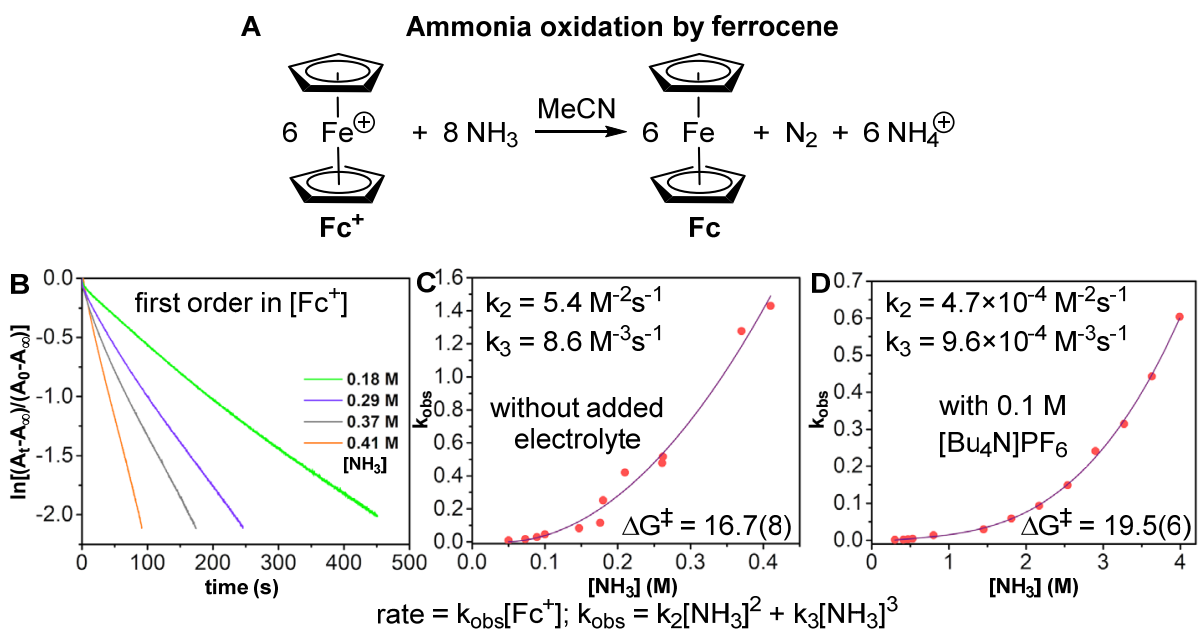

Figure 2 Ammonia oxidation by ferrocenium. (A) Stoichiometric oxidation of ammonia. (B - D) Kinetic plots ammonia oxidation at $25^{\circ} \mathrm{C}$. (B) Pseudo first-order kinetics following loss of [ $\mathrm{Fc}^{+}$]. Plots of $\mathrm{k}_{\text {obs }}\left(\mathrm{s}^{-1}\right)$ vs. $\left[\mathrm{NH}_{3}\right](\mathrm{M})$ in $\mathrm{NH}_{3}$ oxidation by $\mathrm{Fc}^{+}(\mathrm{C})$ without and (D) with added electrolyte. Free energies of activation $\left(\Delta \mathrm{G}^{\ddagger}\right)$ in $\mathrm{kcal} / \mathrm{mol}$ at $298 \mathrm{~K}$. 
Kinetic Analysis of Ammonia Oxidation by Ferrocenium. Kinetic analysis provides further insight into the chemical reactivity between $\mathrm{Fc}^{+}$and $\mathrm{NH}_{3}$. Under conditions of excess ammonia $(0.07-0.41 \mathrm{M})$ in acetonitrile at $25^{\circ} \mathrm{C}$, loss of $\mathrm{Fc}^{+}$(initially $2.4 \mathrm{mM}$ ) is cleanly first-order from which a series of $\mathrm{k}_{\mathrm{obs}}$ values associated with individual $\mathrm{NH}_{3}$ concentrations is obtained (Fig. $2 \mathrm{~B}$ ). To deduce the order in $\left[\mathrm{NH}_{3}\right]$, a plot of $\log \mathrm{k}_{\mathrm{obs}}$ vs. $\log \left[\mathrm{NH}_{3}\right]$ was prepared which gave a slope of 2.55 (Fig. S6B), suggesting that the rate exhibits a combined second and third order dependence on $\left[\mathrm{NH}_{3}\right]$. This results in the experimentally determined rate law: rate $=\left(\mathrm{k}_{2}\left[\mathrm{NH}_{3}\right]^{2}+\mathrm{k}_{3}\left[\mathrm{NH}_{3}\right]^{3}\right)\left[\mathrm{Fc}^{+}\right]$with $\mathrm{k}_{2}=5.4 \mathrm{M}^{-2} \mathrm{~s}^{-1}$ and $\mathrm{k}_{3}=8.6 \mathrm{M}^{3} \mathrm{~s}^{-1}$ at $25{ }^{\circ} \mathrm{C}$ (Fig. 2C). Eyring analysis over the temperature range -20 to $20{ }^{\circ} \mathrm{C}$ estimates the free energy of activation $\Delta \mathrm{G}^{\ddagger}=16.7(8) \mathrm{kcal} / \mathrm{mol}$ with $\Delta \mathrm{H}^{\ddagger}=8.0(5) \mathrm{kcal} / \mathrm{mol}$ and $\Delta \mathrm{S}^{\ddagger}=-29.5(2.1) \mathrm{cal} / \mathrm{mol}$.

Ammonia oxidation by ferrocenium is quite sensitive to ion-pairing effects. While we find that $0.10 \mathrm{M}$ $\left[\mathrm{Bu}_{4} \mathrm{~N}\right] \mathrm{PF}_{6}$ enhances the solubility of $\mathrm{NH}_{3}$ in $\mathrm{MeCN}$, it also results in a significant decrease in rate. Employing an identical initial concentration of $\mathrm{Fc}^{+}(2.4 \mathrm{mM})$, the pseudo first-order rate constant $\left(\mathrm{k}_{\mathrm{obs}}\right)$ for ammonia oxidation is $0.59 \mathrm{~s}^{-1}$ at $\left[\mathrm{NH}_{3}\right]=0.41 \mathrm{M}$ without electrolyte but drops to $0.0016 \mathrm{~s}^{-1}$ in the presence of $0.10 \mathrm{M}\left[\mathrm{Bu}_{4} \mathrm{~N}\right] \mathrm{PF}_{6}$ at this ammonia concentration. The reaction still exhibits a combined second and third order dependence on $\left[\mathrm{NH}_{3}\right]$ over the concentration range $0.30-4.0 \mathrm{M}\left(\mathrm{k}_{2}=4.7 \times 10^{-4}\right.$ $\mathrm{M}^{-2} \mathrm{~s}^{-1} ; \mathrm{k}_{3}=9.6 \times 10^{-3} \mathrm{M}^{-3} \mathrm{~s}^{-1}$ ), but with a higher barrier $\Delta \mathrm{G}^{\ddagger}=19.5(6) \mathrm{kcal} / \mathrm{mol}$ (Fig. 2D).

Computational Analysis of Ammonia Oxidation by Ferrocenium. Recognizing that the $\mathrm{Fc}^{+} / \mathrm{Fc}$ couple can serve as a redox mediator capable of oxidizing substrates in an outer-sphere manner, ${ }^{29,30}$ 1-electron oxidation thermodynamics for ammonia ${ }^{31}$ were evaluated by ab initio and DFT methods to compare these energies against the experimentally determined ionization energy of $\mathrm{Fc}$ to $\mathrm{Fc}^{+}$in $\mathrm{MeCN}(+114.8$ $\mathrm{kcal} / \mathrm{mol}$ ). ${ }^{32}$ MP2/aug-cc-pVTZ/gas//MP2/aug-cc-pVTZ/SMD-MeCN calculations reveal a substantial lowering of the ionization energy of discrete $\mathrm{NH}_{3}$ molecules from $+234.9 \mathrm{kcal} / \mathrm{mol}$ in the gas phase (exp: $232.2(5) \mathrm{kcal} / \mathrm{mol})^{33}$ to $155.2 \mathrm{kcal} / \mathrm{mol}$ in a $\mathrm{MeCN}$ solvent continuum (Fig 3A). Since this ionization is chemically inaccessible from the $\mathrm{Fc}^{+} / \mathrm{Fc}$ couple, instead we considered ionization of the weakly H-bonded ammonia dimer $\left(\mathrm{NH}_{3} \cdot \mathrm{NH}_{3}\right)$. Though ammonia dimerization is endergonic by $6.0 \mathrm{kcal} / \mathrm{mol}$ in $\mathrm{MeCN}$, ionization of $\mathrm{NH}_{3} \cdot \mathrm{NH}_{3}$ to $\left[\mathrm{H}_{2} \mathrm{~N}^{\cdots} \mathrm{HNH}_{3}\right]^{+\bullet}$ is more favorable at $+138.2 \mathrm{kcal} / \mathrm{mol}$, yielding a total free energy of $+144.2 \mathrm{kcal} / \mathrm{mol}$. Conversion of $\left[\mathrm{H}_{2} \mathrm{~N}^{\cdots} \mathrm{HNH}_{3}\right]^{+\bullet}$, an amidyl-ammonium complex loosely held by H-bonding ${ }^{34}$, to hydrazine $\left(\mathrm{N}_{2} \mathrm{H}_{4}\right)$ and ammonium $\left(\mathrm{NH}_{4}{ }^{+}\right)$is significantly downhill $(\Delta \mathrm{G}=-32.7$ $\mathrm{kcal} / \mathrm{mol}$ ). Nonetheless, the 1 -electron ionization of 2 equiv. $\mathrm{NH}_{3}$ proceeding via $\left[\mathrm{H}_{2} \mathrm{~N}^{\cdots} \mathrm{HNH}_{3}\right]^{+\bullet}$ is still $29.4 \mathrm{kcal} / \mathrm{mol}$ uphill from the $\mathrm{Fc}^{+} / \mathrm{Fc}$ couple. DFT methods previously examined for ammonia clusters (M06-2X, B3LYP-D3) ${ }^{34,35}$ similarly predict ionization energies for the ammonia dimer in MeCN over 25 $\mathrm{kcal} / \mathrm{mol}$ above the experimentally determined $\mathrm{Fc}^{+} / \mathrm{Fc}$ couple (Fig 3B, Table S6). All of these thermodynamic values for ammonia oxidation are considerably higher than the experimentally measured free energy of activation of $16.7(8) \mathrm{kcal} / \mathrm{mol}$ for ammonia oxidation by $\mathrm{Fc}^{+}$. 


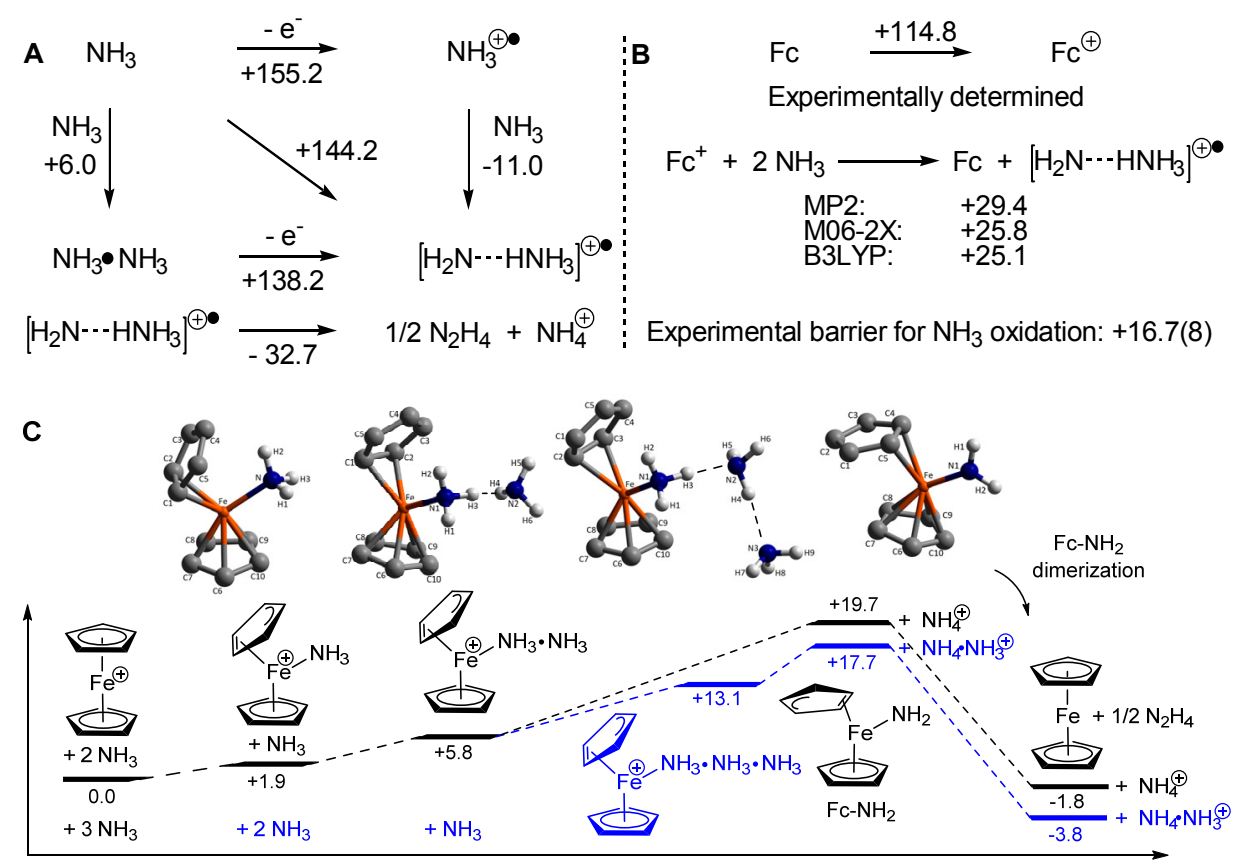

Figure 3 Computational analysis of ammonia oxidation by $\mathbf{F c}^{+}$. (A) Ionization of ammonia and ammonia dimer with free energies from the MP2/aug-cc-pVTZ/gas//MP2/aug-cc-pVTZ/SMD-MeCN level of theory. (B) Thermodynamics of outer-sphere ammonia oxidation by ab initio and DFT methods compared with the experimental ionization energy of $\mathrm{Fc}$ in $\mathrm{MeCN}{ }^{32}$ (C) Inner-sphere oxidation of $\mathrm{NH}_{3}$ by $\mathrm{Fc}^{+}$at the B3LYP-GD3BJ/6-311++G(d,p)/SMD-acetonitrile level of theory. All free energies in $\mathrm{kcal} / \mathrm{mol}$ at $298 \mathrm{~K}$.

As the combination of experimental and computational data weigh against an outer-sphere electron transfer mechanism, an inner-sphere mechanism was considered that involves coordination of $\mathrm{NH}_{3}$ to $\mathrm{Fc}^{+}$ to give $\left[\mathrm{Fc}-\mathrm{NH}_{3}\right]^{+}$(Fig. 3C). Indeed, ferrocenium functions as a Lewis acid catalyst in a number of organic transformations. ${ }^{30}$ We employed DFT at the B3LYP+GD3BJ/6-311++G(d,p)/SMD-MeCN level of theory that predicts the $\mathrm{Fc} / \mathrm{Fc}^{+}$couple at $116.9 \mathrm{kcal} / \mathrm{mol}$ in $\mathrm{MeCN}$ (exp: $114.8 \mathrm{kcal} / \mathrm{mol}$ ). ${ }^{32}$ Coordination of ammonia to give $\left[\mathrm{Fc}-\mathrm{NH}_{3}\right]^{+}$is only slightly endergonic $(\Delta \mathrm{G}=+1.9 \mathrm{kcal} / \mathrm{mol})$ with a minimal barrier $\left(\Delta \mathrm{G}^{*}=4.5 \mathrm{kcal} / \mathrm{mol}\right)$ despite the slippage of one $\mathrm{Cp}$ ring from $\eta^{5}$ to $\eta^{2}$. The interaction of $\mathrm{NH}_{3}$ with $\mathrm{Fc}^{+}\left(\mathrm{Fe}-\mathrm{NH}_{3}=2.03 \AA\right)$ enhances the N-H acidity of the ammine ligand enabling formation of the H-bonded intermediates $\left[\mathrm{Fc}-\mathrm{NH}_{3}{ }^{\cdots} \mathrm{NH}_{3}\right]^{+}$and $\left[\mathrm{Fc}-\mathrm{NH}_{3}{ }^{\cdots} \mathrm{NH}_{3}{ }^{\cdots} \mathrm{NH}_{3}\right]^{+}$at +5.8 and $+13.1 \mathrm{kcal} / \mathrm{mol}$ from $\mathrm{Fc}^{+}$, respectively. These species may precede deprotonation of the $\left[\mathrm{Fc}-\mathrm{NH}_{3}\right]^{+}$moiety to give the neutral iron amide $\left[\mathrm{Fc}-\mathrm{NH}_{2}\right]\left(\mathrm{Fe}-\mathrm{NH}_{2}=1.81 \AA\right)$ and either $\mathrm{NH}_{4}{ }^{+}$or $\left[\mathrm{NH}_{4} \bullet \mathrm{NH}_{3}\right]^{+}$with thermodynamic barriers $\Delta \mathrm{G}$ $=19.7$ or $17.7 \mathrm{kcal} / \mathrm{mol}$ from $\mathrm{Fc}^{+}$, respectively. Relaxed potential energy scans involving deprotonation to $\left[\mathrm{Fc}-\mathrm{NH}_{2}\right]$ from $\left[\mathrm{Fc}-\mathrm{NH}_{3} \cdots \mathrm{NH}_{3}\right]^{+}$and $\left[\mathrm{Fc}-\mathrm{NH}_{3} \cdots \mathrm{NH}_{3}{ }^{\cdots} \mathrm{NH}_{3}\right]^{+}$did not reveal barriers above these thermodynamic values. These competing deprotonation pathways to form the high energy $\mathrm{Fc}-\mathrm{NH}_{2}$ intermediate are consistent with the experimentally observed rate law that exhibits a mixed second- and third-order dependence on the ammonia concentration. Finally, bimolecular coupling of $\mathrm{Fc}-\mathrm{NH}_{2}$ to give hydrazine and ferrocene is exergonic by $21.5 \mathrm{kcal} / \mathrm{mol}$ (per Fc). 
While these mechanistic considerations predict hydrazine as a product of the 1-electron oxidation of ammonia, we do not experimentally detect hydrazine. Addition of 20 equiv. hydrazine to $\mathrm{Fc}^{+}$in $\mathrm{MeCN}$ at RT $\left(\left[\mathrm{Fc}^{+}\right]_{\mathrm{o}}=3.1 \mathrm{mM}, \mathrm{t}_{1 / 2}<<1 \mathrm{~s}\right)$ instantly reduces $\mathrm{Fc}^{+}$and gives $\mathrm{N}_{2}$ in $93 \%$ experimental yield (eq 1 ). Thus, hydrazine would not be observed in the slower reaction of $\mathrm{Fc}^{+}$with ammonia. These findings are consistent with the use of the 1,1'-dicarboxylic acid derivative of ferrocene as an electrocatalyst for the oxidation of hydrazine in aqueous solution. ${ }^{36}$

$4 \mathrm{Fc}^{+}+\mathrm{N}_{2} \mathrm{H}_{4} \stackrel{\mathrm{MeCN}}{\longrightarrow} 4 \mathrm{Fc}+\mathrm{N}_{2}+4 \mathrm{H}^{+}(1)$

Electrocatalytic Ammonia Oxidation by Ferrocene. Cyclic voltammetry of $1.0 \mathrm{mM}$ Fc in $3.6 \mathrm{M} \mathrm{NH}_{3}$ / $\mathrm{MeCN}$ using a $0.07 \mathrm{~cm}^{2}$ glassy carbon (GC) electrode in the presence of $0.1 \mathrm{M}\left[\mathrm{Bu}_{4} \mathrm{~N}\right] \mathrm{PF}_{6}$ showed large, irreversible oxidative waves at different scan rates that correspond to electrocatalytic ammonia oxidation (Fig. 4A). Thus, catalyzed ammonia oxidation in $\mathrm{MeCN}$ occurs at a potential approximately $420 \mathrm{mV}$ lower than in the absence of ferrocene (Fig. S14A) ${ }^{31}$ Controlled potential electrolysis (CPE) for $13 \mathrm{~h}$ using a $10 \mathrm{~cm}^{2}$ reticulated vitreous carbon (RVC) electrode in a $10 \%$ ammonia: MeCN (v:v) solution (ca. $4.6 \mathrm{M}$ ) at $-10{ }^{\circ} \mathrm{C}$ with $1.0 \mathrm{mM}$ Fc produced $\mathrm{N}_{2}$ with a Faradaic yield of $44 \%$ (Fig. 4B). Analysis of the recovered Fc catalyst on a separate, polished GC electrode revealed only a $10 \%$ loss of electrochemical activity when compared against a fresh Fc / electrolyte solution.
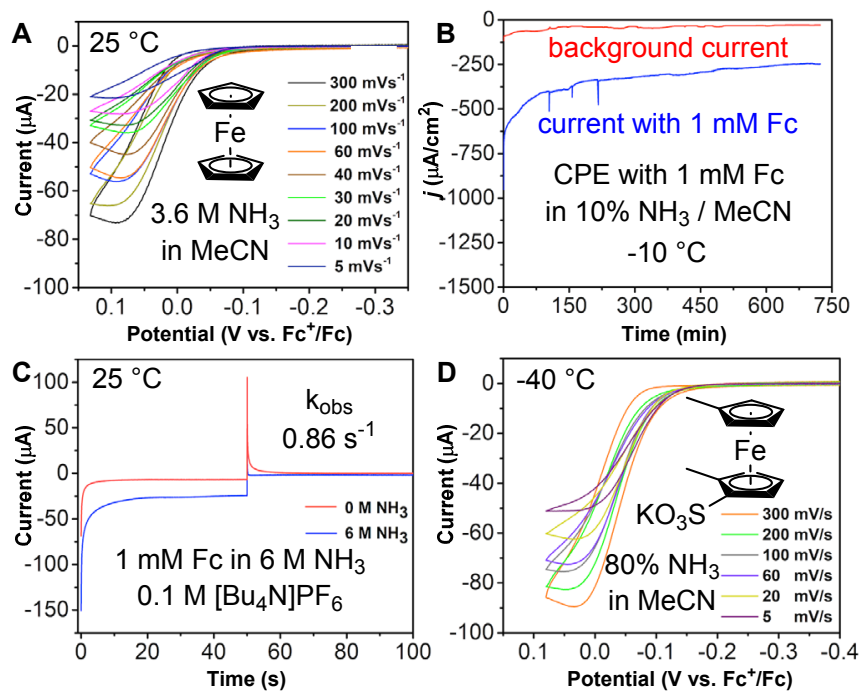

Figure 4 | Electrocatalytic ammonia oxidation by ferrocenes. (A) Cyclic voltammetry of $\mathrm{Fc}$ in $3.6 \mathrm{M}$ $\mathrm{NH}_{3} / \mathrm{MeCN}$ with $0.1 \mathrm{M}\left[\mathrm{Bu}_{4} \mathrm{~N}\right] \mathrm{PF}_{6}$. (B) Controlled potential electrolysis of ammonia catalyzed by ferrocene. (C) Double potential step chromoamperometry of $\mathrm{Fc}$ in $6 \mathrm{M} \mathrm{NH}_{3}$. (D) $\mathrm{CV}$ of sulfonated ferrocene in $80 \% \mathrm{NH}_{3} / \mathrm{MeCN}$ with $0.1 \mathrm{M} \mathrm{KPF}_{6}$ at $-40{ }^{\circ} \mathrm{C}$. 
Beyond experimental limitations in $\mathrm{N}_{2}$ collection, we considered the possibility of a lowered Faradaic yield due to electrode modification under electrocatalytic conditions. Chronoamperometry at $+0.05 \mathrm{~V}$ vs. $\mathrm{Fc}^{+} / \mathrm{Fc}$ using a $0.07 \mathrm{~cm}^{2} \mathrm{GC}$ electrode with $1 \mathrm{mM} \mathrm{Fc}$ in $4 \mathrm{M} \mathrm{NH}_{3} / \mathrm{MeCN}$ demonstrates a stable catalytic current during the first $2 \mathrm{~min}$ followed by a substantial decrease in current after $10 \mathrm{~min}(86 \%)$. Under the identical conditions, a similarly-sized edge plane pyrolytic graphite (EPPG) working electrode ${ }^{37}$ provides a longer-lasting current stable for $5 \mathrm{~min}$, but also gradually decays after $10 \mathrm{~min}$ (49\%) (Fig. S15).

Thus, an EPPG electrode was utilized in double potential step chronoamperometry experiments to calculate the rate constant in the electrocatalytic reaction between $\mathrm{Fc}^{+}(1.0 \mathrm{mM})$ and $\mathrm{NH}_{3}(6 \mathrm{M})$ in the presence of $0.1 \mathrm{M}\left[\mathrm{Bu}_{4} \mathrm{~N}\right] \mathrm{PF}_{6}$ in $\mathrm{MeCN}$ at RT. Using an oxidative step interval $(50 \mathrm{~s})$ that results in a stable current at $0.05 \mathrm{~V}$ vs. $\mathrm{Fc}^{+} / \mathrm{Fc}$, a rate constant $\mathrm{k}_{\mathrm{obs}}=0.86 \mathrm{~s}^{-1}$ was calculated from the slope of $i_{\mathrm{c}} / i_{\mathrm{p}} \mathrm{vs}$. $\mathrm{t}^{-1 / 2}$ (Figs. 4C and S17). This value is comparable to that expected in the chemical reaction of $\mathrm{Fc}^{+}$with 6 $\mathrm{M} \mathrm{NH}_{3}$ in the presence of $0.1 \mathrm{M}\left[\mathrm{Bu}_{4} \mathrm{~N}\right] \mathrm{PF}_{6}\left(\right.$ Fig. 2D; extrapolated $\left.\mathrm{k}_{\mathrm{obs}}=2.1 \mathrm{~s}^{-1}\right)$.

$2 \mathrm{NH}_{3} \stackrel{\mathrm{MeCN}}{\rightleftharpoons} \mathrm{N}_{2}+6 \mathrm{NH}_{4}^{+}+6 \mathrm{e}^{-} \mathrm{E}=-0.94 \mathrm{Vvs.} \mathrm{Fc}^{+} / \mathrm{Fc}$

The thermodynamics of the $\mathrm{N}_{2} / \mathrm{NH}_{3}$ redox couple have recently been considered in MeCN. ${ }^{38}$ When excess $\mathrm{NH}_{3}$ is used to capture protons generated in the oxidation of $\mathrm{NH}_{3}$, the potential has been assigned as $-0.94 \mathrm{~V}$ vs. $\mathrm{Fc}^{+} / \mathrm{Fc}$ (eq. 2). ${ }^{38}$ Thus, ferrocene exhibits an overpotential $\eta \approx 940 \mathrm{mV}$ for ammonia oxidation under these conditions. To lower the overpotential, we have preliminarily explored somewhat more electron-rich ferrocenes with lower $\mathrm{Fc}^{\text {' }} / \mathrm{Fc}^{\prime}$ redox potentials such as $1,1^{\prime}-\mathrm{Me}_{2} \mathrm{Fc}\left(\mathrm{E}_{1 / 2}=-0.130 \mathrm{~V} ; \eta\right.$ $\approx 810 \mathrm{mV})$ and $1,1^{\prime}-\mathrm{Me}_{2} \mathrm{FcSO}_{3} \mathrm{~K}\left(\mathrm{E}_{1 / 2}=-0.120 \mathrm{~V} ; \eta \approx 820 \mathrm{mV}\right)$. While these substituted ferrocenes function as electrocatalysts, they also result in lower rates for ammonia oxidation in $6 \mathrm{M} \mathrm{NH}_{3} / \mathrm{MeCN}$ $\left(\mathrm{k}_{\mathrm{obs}}=0.20\right.$ and $0.11 \mathrm{~s}^{-1}$, respectively) (Figs. S18 - S19). The electron-rich, yet sterically congested $\left(\eta^{5}-\mathrm{C}_{5} \mathrm{Me}_{5}\right)_{2} \mathrm{Fe}\left(\mathrm{E}_{1 / 2}=-0.590 \mathrm{~V}\right.$ vs. $\left.\mathrm{Fc}^{+} / \mathrm{Fc}\right)$ does not show electrocatalytic oxidation of ammonia under these conditions.

Importantly, the sulfonated ferrocene $1,1^{\prime}-\mathrm{Me}_{2} \mathrm{FcSO}_{3} \mathrm{~K}$ is soluble in liquid ammonia at $-40{ }^{\circ} \mathrm{C}$. $\mathrm{CV}$ experiments in a $80: 20(\mathrm{v}: \mathrm{v})$ mixture of $\mathrm{NH}_{3}$ and $\mathrm{MeCN}$ at $-40{ }^{\circ} \mathrm{C}$ with $\mathrm{KPF}_{6}$ as electrolyte reveal electrocatalysis (Fig. 4D) and CPE for $8 \mathrm{~h}$ at $-40{ }^{\circ} \mathrm{C}$ produces $\mathrm{N}_{2}$ with a Faradaic yield of $35 \%$. Although the recovered catalyst exhibits a significant loss in electrochemical activity (Fig. S24), these results nonetheless establish the viability of molecular electrocatalysts to generate $\mathrm{N}_{2}$ and current from highly concentrated ammonia solutions. 


\section{Discussion and Conclusion}

Ferrocenium efficiently oxidizes ammonia to nitrogen along with protons and electrons captured as ammonium and ferrocene, respectively, resulting in a robust electrocatalytic system. Based on Earth-abundant iron, this system offers significant promise in terms of sustainability and cost as compared to systems that employ precious metals for the extraction of electrical energy from ammonia as part of a carbon-free fuel cycle.

Mechanistic studies indicate that the reaction between $\mathrm{Fc}^{+}$and $\mathrm{NH}_{3}$ is first-order in $\left[\mathrm{Fc}^{+}\right]$with competing second- and third-order pathways in $\left[\mathrm{NH}_{3}\right]$ supported by computational studies that outline deprotonation of a $\mathrm{Fc}^{+}$-bound $\mathrm{NH}_{3}$ by one or two equiv. $\mathrm{NH}_{3}$ to give a highly reactive $\mathrm{Fc}-\mathrm{NH}_{2}$ species. This iron-amide is quite susceptible to N-N coupling to form hydrazine which experimentally undergoes oxidation to $\mathrm{N}_{2}$ by $\mathrm{Fc}^{+}$faster than ammonia. Electrochemical cycling of reduced $\mathrm{Fc}$ with oxidized $\mathrm{Fc}^{+}$enables the electrocatalytic oxidation of ammonia that produces sustained current at carbon-based electrodes. These studies also identify the importance of the electrode materials, highlighting the improved performance of EPPG over GC electrodes in electrocatalysis.

Building upon these insights, the hundreds of ferrocene derivatives known ${ }^{26}$ underscore the promise of this framework for the development of ammonia oxidation electrocatalysts with decreased overpotentials and improved rates. For instance, simple synthetic modification enables access to ferrocene derivatives such as $1,1^{\prime}-\mathrm{Me}_{2} \mathrm{FcSO}_{3} \mathrm{~K}$ that function as electrocatalysts in energy-dense, highly concentrated ammonia solutions. The ability to graft ferrocenes onto GC electrodes ${ }^{39}$ may allow extension of the homogeneous advances reported herein to solid-state electrodes that function as heterogeneous electrocatalysts. Furthermore, these advances may enable new approaches for the environmental remediation of ammonia, a key nitrogen pollutant in wastewater. ${ }^{14}$

\section{Acknowledgements}

THW acknowledges support from the U.S. Department of Energy, Office of Science, Basic Energy Sciences (DE-SC001779). This research was funded in part by the Georgetown Environment Initiative. We are grateful for discussions with Prof. Tom Cundari of the University of North Texas.

\section{Additional information}

The authors declare no competing financial interests. Correspondence and requests for materials should be addressed to T.H.W. 


\section{References}

1. J. Guo, P. Chen, Catalyst: $\mathrm{NH}_{3}$ as an energy carrier. Chem 3, 709-712 (2017).

2. S. Giddey, S. P. S. Badwal, C. Munnings, M. Dolan, Ammonia as a renewable energy transportation media. ACS Sustain. Chem. Eng. 5, 10231-10239 (2017).

3. R. Lan, J. Irivine, S. Tao, Ammonia and related chemicals as potential indirect hydrogen storage materials. Int. J. Hydrogen Energy 37, 1482-1494 (2012).

4. United States Geological Survey, National Minerals Information Center, "Nitrogen Statistics and Information"; https://www.usgs.gov/centers/nmic/nitrogen-statistics-and-information.

5. A. Klerke, C. H. Christensen, J. K. Nørskov, T. Vegge, Ammonia for hydrogen storage: challenges and opportunities. J. Mater. Chem. 18, 2304-2310 (2008).

6. S. Z. Andersen et al., A rigorous electrochemical ammonia synthesis protocol with quantitative isotope measurements. Nature 570, 504-508 (2019).

7. F. Jiao, B. Xu, Electrochemical ammonia synthesis and ammonia fuel cells. Advanced Materials 31, 1805173 (2019).

8. Y. Zhao et al., An efficient direct ammonia fuel cell for affordable carbon-neutral transportation. Joule 3, doi: 10.1016/j.joule.2019.1007.1005 (2019).

9. Y.-R. Luo, Handbook of Bond Dissociation Energies in Organic Compounds. (CRC Press, Boca Raton, FL, 2002).

10. S. Mukherjee, S. V. Devaguptapu, A. Sviripa, C. R. F. Lund, G. Wu, Low-temperature ammonia decomposition catalysts for hydrogen generation. Appl. Catal. B Environ. 226, 162-181 (2018).

11. N. Hanada et al., Hydrogen generation by electrolysis of liquid ammonia. Chem. Commun. 46, 7775-7777 (2010).

12. D. J. Little, M. R. Smith III, T. W. Hamann, Electrolysis of liquid ammonia for hydrogen generation. Energy Environ. Sci. 8, 2775-2781 (2015).

13. D. J. Little, D. O. Edwards, M. R. Smith, T. W. Hamann, As precious as platinum: iron nitride for electrocatalytic oxidation of liquid ammonia. ACS Appl. Mater. Interfaces 9, 16228-16235 (2017).

14. N. M. Adli, H. Zhang, S. Mukherjee, G. Wu, Review — ammonia oxidation electrocatalysis for hydrogen generation and fuel cells. J. Electrochem. Soc. 165, J3130-J3147 (2018).

15. C. Zhong, W. B. Hu, Y. F. Cheng, Recent advances in electrocatalysts for electro-oxidation of ammonia. J. Mater. Chem. A 1, 3216-3238 (2013). 
16. R. Matheu, M. Z. Ertem, C. Gimbert-Suriñach, X. Sala, A. Llobet, Seven coordinated molecular ruthenium-water oxidation catalysts: A coordination chemistry journey. Chem. Rev. 119, 3453-3471 (2019).

17. A. Corma, Heterogeneous catalysis: understanding for designing, and designing for applications. Angew. Chem. Int. Ed. 55, 6112-6113 (2016).

18. O. Ishitani, P. S. White, T. J. Meyer, Formation of dinitrogen by oxidation of $\left[(\text { bpy })_{2}\left(\mathrm{NH}_{3}\right) \mathrm{RuORu}\left(\mathrm{NH}_{3}\right)(\text { bpy })_{2}\right]^{4+}$. Inorg. Chem. 35, 2167-2168 (1996).

19. S. I. Johnson et al., Design and reactivity of pentapyridyl metal complexes for ammonia oxidation. Chem. Commun. 55, 5083-5086 (2019).

20. G. M. Coia, K. D. Demadis, T. J. Meyer, Oxidation of ammonia in osmium polypyridyl complexes. Inorg. Chem. 39, 2212-2223 (2000).

21. M. J. Bezdek, S. Guo, P. J. Chirik, Coordination-induced weakening of ammonia, water, and hydrazine X-H bonds in a molybdenum complex. Science 354, 730-733 (2016).

22. F. Habibzadeh, S. L. Miller, T. W. Hamann, M. R. Smith III, Homogeneous electrocatalytic oxidation of ammonia to $\mathrm{N}_{2}$ under mild conditions. Proc. Natl. Acad. Sci. USA 116, 2849-2853 (2019).

23. P. Bhattacharya et al., Catalytic ammonia oxidation to dinitrogen by hydrogen atom abstraction. Angew. Chem. Int. Ed. 58, doi: 10.1002/anie.201903221 (2019).

24. K. Nakajima, H. Toda, K. Sakata, Y. Nishibayashi, Ruthernium-catalyzed oxidative conversion of ammonia into dinitrogen. Nature Chem. 11, 702-709 (2019).

25. A. A. J. Torriero, M. J. A. Shiddiky, I. Burgar, A. M. Bond, Homogeneous electron-transfer reaction between electrochemically generated ferrocenium ions and amine- containing compounds. Organometallics 32, 5731-5739 (2013).

26. D. Astruc, Why is ferrocene so exceptional? Eur. J. Inorg. Chem. 2017, 6-29 (2017).

27. N. G. Connelly, W. E. Geiger, Chemical redox agents for organometallic chemistry. Chem. Rev. 96, 877-910 (1996).

28. G. Gritzner, J. Kuta, Recommendations on reporting electrode potentials in nonaqueous solvents. J. Pure Appl. Chem. 56, 461-466 (1984).

29. S. D. Waniek, J. Klett, C. Förster, K. Heinze, Polysubstituted ferrocenes as tunable redox mediators. Beilstein J. Org. Chem. 14, 1004-1015 (2018).

30. $\quad \breve{S}$. Toma, R. Šebesta, Applications of ferrocenium salts in organic synthesis. Synthesis $\mathbf{4 7}$, 1683-1695 (2015). 
31. Z. J. Schiffer, N. Lazouski, N. Corbin, K. Manthiram, Nature of the first electron transfer in electrochemical ammonia activation in a nonaqueous medium. J. Phys. Chem. C 123, 9713-9720 (2019).

32. M. Namazian, C. Y. Lin, M. L. Coote, Benchmark calculations of absolute reduction potential of ferricinium/ferrocene couple in nonaqueous solutions. J. Chem. Theory Comput. 6, 2721-2725 (2010).

33. National Institute of Standards and Technology (NIST) Chemistry WebBook, "Ammonia"; https://webbook.nist.gov/cgi/cbook.cgi?ID=C7664417.

34. J. Chalabala, P. Slavíček, Nonadiabatic dynamics of floppy hydrogen bonded complexes: the case of the ionized ammonia dimer. Phys. Chem. Chem. Phys. 18, 20422-20432 (2016).

35. A. Malloum, J. J. Fifen, Z. Dhaouadi, S. G. N. Engoa, N.-E. Jaidane, Structures and relative stabilities of ammonia clusters at different temperatures: DFT vs. ab initio. Phys. Chem. Chem. Phys. 17, 29226-29242 (2015).

36. J.-B. Raoof, R. Ojani, Z. Mohammadpour, Electrocatalytic oxidation and voltammetric determination of hydrazine by 1,1'-ferrocenedicarboxylic acid at glassy carbon electrode. Int. J. Electrochem. Sci. 5, 177-188 (2010).

37. W. Zhang et al., Recent development of carbon electrode materials and their bioanalytical and environmental applications. Chem. Soc. Rev. 45, 715-752 (2016).

38. B. M. Lindley, A. M. Appel, K. Krogh-Jespersen, J. M. Mayer, A. J. M. Miller, Evaluating the thermodynamics of electrocatalytic $\mathrm{N}_{2}$ reduction in acetonitrile. ACS Energy Lett. 1, 698-704 (2016).

39. V. Jouikov, J. Simonet, Novel method for grafting alkyl chains onto glassy carbon. Application to the easy immobilization of ferrocene used as redox probe. Langmuir $\mathbf{2 8}$, 931-938 (2011). 